Est Ag 46 (2011) 33-68

\title{
EI desarrollo de la misión de la vida religiosa durante la época del Concilio Vaticano II y el periodo posconciliar
}

\author{
Ma Ascensión Matás García, OP*
}

RESUMEN: Las problemáticas surgidas entre los años 60 y los 90 impulsaron a la vida religiosa a repensar su identidad dentro de la comunión eclesial, invitándola al retorno a las fuentes de toda vida cristiana, a la inspiración originaria de cada Instituto y a la adaptación de cada uno de ellos a los nuevos tiempos, tomando como regla el seguimiento de Cristo y haciendo de la comunidad fermento de renovación y sujeto de una misión llamada a ser liberación total del hombre y de todo hombre.

PALABRAS CLAVE: Vida religiosa, misión, Vaticano II, Perfectae Caritatis, renovación.

ABSTRACT: From the sixties to the nineties of the past century, different circumstances move the Religious Life to review its own identity inside the ecclesial communion, inviting it to turn back to the sources of the christian life, to the original inspiration of each Institute and to adapt them to the present time. Always taking the following of Christ as a rule and making the community a seed of renewal and leading a mission called to the total liberation of the human being and of every single man.

KEY WORDS: Religious Life, Mission, Vatican II, Perfectae Caritatis, Renewal.

Durante el período correspondiente a la época conciliar y posconciliar se puso de relieve la pertenencia de la vida religiosa a la comunión eclesial. Se

${ }^{*}$ Profesora del Estudio Teológico Agustiniano de Valladolid.

mascen.matas@yahoo.es. 
fomentó una visión más dinámica de dicho género de vida, apoyada en el retorno a la inspiración originaria de los Institutos, así como a la adaptación de los mismos, a las condiciones cambiantes de los tiempos. Haciendo patente su misión de salvación en el mundo y del mundo, para la liberación total del hombre y de todo hombre, a través de la redención integral de las culturas.

\section{A. La década de los 60}

Las problemáticas y las novedades sociales y eclesiales surgidas durante la década de los 60 , hicieron preciso el desarrollo de una reflexión teológica sobre la vida religiosa, que determinase de modo más matizado su ubicación dentro de una Iglesia, a la que el Concilio Vaticano II definió bajo la categoría central de «Pueblo de Dios». Durante este período se hizo hincapié en la tarea evangelizadora de la vida religiosa, sustentándola, entre otros elementos, en el diálogo con el mundo moderno y en la profundización de las bases teológicas y antropológicas de la comunidad religiosa.

\section{Durante el Concilio}

La vida religiosa llegó al Concilio Vaticano II tras unos ciento cincuenta años de gran esplendor, caracterizados por la fundación de casi cuatrocientos Institutos, que intentaron dar respuesta a las necesidades surgidas a raíz de la expansión de Europa y de sus consecuentes procesos de industrialización ${ }^{1}$.

Particularmente significativa fue la presencia de los Institutos femeninos, los cuales alcanzaron la plena autonomía jurídica a mediados del ochocientos, con el reconocimiento de la figura de la Superiora general y se sumergieron en un creciente movimiento misionero, que con heroísmos increíbles, contribuyó a la evangelización de África y de otros continentes ${ }^{2}$.

De este modo se facilitaron numerosas oportunidades de movilidad social, a aquellas jóvenes deseosas de abrazar la vida religiosa, ofreciéndoles no sólo las motivaciones del empeño cristiano, sino también las modalidades concretas con las cuales poder llevar a la práctica los grandes deseos

\footnotetext{
${ }^{1}$ J. M. PIÑERo, “Órdenes Religiosas”, en AA. VV., Historia de la Espiritualidad, 2 vol., Barcelona 1969, 509-516.

${ }^{2} \mathrm{Cf}$. Cl. LANGLOIS, Le catholicisme au feminin: les congrégations françaises à supérieure générale au XIXe siècle, Paris 1984.
} 
de servir a los más desprotegidos de la sociedad, saliendo de un mundo cerrado, para abrirse a horizontes cada vez más vastos.

La vida religiosa fue considerada por el clero y el pueblo cristiano, como la vía regia de la santidad, de la cual dependía la formación de la mayor parte de los cristianos, quienes nutrían su espiritualidad con la lectura de textos escritos por o para religiosos, tales como las obras de San Francisco de Sales, de Santa Teresa de Ávila, de San Alfonso M ${ }^{\mathrm{a}}$ de Ligorio y de tantos otros autores espirituales.

El gran prestigio externo del que gozaba dicho género de vida, se apoyaba en una fuerte base ascética, que se esforzaba por dar lugar a personas que trabajasen por Dios y por los hermanos, mediante un aprendizaje basado en el dóminio de sí y la dedicación a los otros. La santificación se interpretaba desde una marcada predilección por la uniformidad de los comportamientos, sustentada por la detallada normativa del Código de Derecho Canónico, así como por la observancia de la Regla, el trabajo asiduo, la obediencia a los Superiores y la caridad fraterna. A su vez, las devociones fueron un fenómeno muy extendido durante este período, que cuando eran bien vividas, movilizaban todas las facultades de la persona, orientando sus energías, hacia las grandes metas espirituales.

Sin embargo, también se dieron notorios signos de debilidad dentro de aquella vida religiosa, que si bien fue en gran parte promotora de la renovación eclesial iniciada con el Concilio Vaticano II, no pareció vivirla en su seno. Basta recordar a los numerosos religiosos que promulgaron el movimiento bíblico (los Dominicos de la École biblique de Jerusalén, los Jesuitas del Pontificio Instituto Bíblico...), el movimiento patrístico (Jean Daniélou, Henri De Lubac, Yves Marie-Joseph Congar...) o el movimiento litúrgico (la abadía benedictina de Maria Laach, el monasterio benedictino de Beuron...), quienes paradójicamente solían aparecer como los profetas rechazádos dentro de la vida religiosa y escuchados por el pueblo cristiano.

A ello se sumó una progresiva disminución en el número de las vocaciones, dando lugar al nacimiento de la Pastoral vocacional, a veces considerada bajo el calificativo de alistamiento, especialmente por parte de las Congregaciones misioneras.

Progresivamente se fue difundiendo un sentido de intolerancia hacia una autoridad considerada demasiado paternalista, frente al clima cada vez más democrático que se respiraba en Occidente; hacia el excesivo protagonismo concedido a la Regla y a una obediencia que a veces era manipulada en vistas a frenar la innovación, justo cuando la sociedad entraba en un movimiento de cambio veloz; hacia la uniformidad impuesta por el Código de Derecho Canónico, que impedía adecuar las formas de vida religiosa a 
los nuevos apostolados. Por otra parte se hacía urgente una mayor formación, especialmente en la vida religiosa femenina, insertada en una sociedad que estaba creciendo culturalmente y solicitaba competencias nuevas y una mayor profesionalidad.

De este conjunto de problemáticas y de las novedades nacidas no sólo dentro de la sociedad, sino también de la Iglesia, surgió la conciencia de establecer una reflexión sobre la vida religiosa, no tan ascética, como hasta el momento, sino más teológica, que determinase de modo más global y matizado su identidad y la repensase dentro de la comunión eclesial, respecto a los nuevos sujetos eclesiales emergentes.

La vida religiosa obtuvo un capítulo específico en la Constitución dogmática Lumen Gentium (LG), entre el capítulo V, que versa sobre la llamada universal a la santidad y el capítulo VII, que trata sobre la índole escatológica de la Iglesia, dando así respuesta a su autocomprensión teológica dentro de la eclesiología clásica, que era sustancialmente aquella de las dos vías. De este modo fue considerada como un tipo de vida particularmente significativo, que pertenece indisoluble y firmemente a la vida y santidad de la Iglesia ${ }^{3}$ e impulsa a los otros géneros de vida hacia el radicalismo evangélico. A su vez, facilita a sus miembros el trabajar, según la propia vocación, por implantar o fortalecer en cada hombre el Reino de Cristo y extenderlo por el mundo (LG 43-44).

El Decreto conciliar Perfectae Caritatis (PC) ofreció una visión histórico-existencial de la vida religiosa, invitando a su renovación y a una visión más dinámica y práctica de la misma, apoyada en el continuo retorno a las fuentes de toda vida cristiana y a la inspiración originaria de los Institutos, así como a la adaptación de los mismos, a las condiciones de los tiempos. Para ello exhortó a considerar al seguimiento de Cristo, como la regla suprema de la vida religiosa; a conocer y conservar con fidelidad el espíritu y los propósitos de los Fundadores y las sanas tradiciones del Instituto; a participar en la vida de la Iglesia y fomentar sus iniciativas; a promover entre los religiosos un conocimiento adecuado de las condiciones de los hombres y de los tiempos, así como de las necesidades de la Iglesia; acompañar los cambios externos, por una correspondiente renovación espiritual (PC 2).

Particularmente influyentes fueron los documentos sobre la Palabra de Dios, Dei Verbum (DV), y sobre la liturgia, Sacrosanctum Concilium

3 "La vida religiosa pertenece inalienablemente a la Iglesia cuando ésta sea contemplada en el acto de responder a la llamada de su Señor, cuando realiza su misión, su bien común y su fin de santidad; en resumen cuando vive lo que está llamada a ser" (Prefacio a AA. VV., La renovación de la vida religiosa, Firense 1968, 14). 
(SC), de los que partió una forma de orar, más centralizada en la Palabra y un profundo sentido de la celebración del misterio cristiano, con una consiguiente decadencia de devociones particulares, junto a una necesaria redefinición de la espiritualidad de numerosos Institutos. Pero también la Constitución pastoral Gaudium et Spes (GS) tuvo un notable impacto sobre la Iglesia y por tanto, sobre la vida religiosa, con su exhortación a no aislarse del mundo, sino a dialogar con él y a comunicarle la buena nueva de la salvación, sintiéndose íntima y realmente solidaria con el género humano y su historia (GS 1).

De este modo se pasó de la Regla al Evangelio, convirtiendo al seguimiento de Cristo en la realidad fundante de la vida religiosa, al Evangelio en su "norma normans" y a la Regla, en una especificación del mismo y en un medio particularmente apto para seguir a Jesucristo; de la autoridad a la hermandad, pasando del ser superior-súbditos, a ser hermanos, convocados por Cristo y unidos por recíprocos vínculos de amor; de la fuga del mundo al deseo de conocerlo, pasando del ser visto como el mundo del pecado, a ser considerado también como el mundo rico de valores, conquistas y esperanzas.

\section{Después del Concilio}

Los primeros años del post Concilio asistieron a una de las más veloces y fundamentales transformaciones acaecidas en la historia de la humanidad, gracias a aquella Edad de oro del capitalismo, que puso fin a siete $\mathrm{u}$ ocho milenios de la historia humana, iniciados en la Edad de la piedra con la invención de la agricultura, para dar paso a la civilización tecnológica. Ésta difundió un clima de optimismo, basado en las enormes posibilidades que la ciencia y la razón parecían ofrecer en vistas de un porvenir mejor.

En la revolución del 68 se manifestó el deseo de analizar críticamente la realidad, más allá de la retórica y del conformismo, bajo la utopía de originar una sociedad alternativa a aquella dominada por el provecho, donde estuviese "prohibido prohibir" y la creatividad apareciese como un prodigioso cauce para solucionar los problemas que iban surgiendo. Se creó así una cadena de movimientos, que sustituyeron a la democratización por el lema de que todo tiene que ser decidido por todos, con el frecuente estallido de discusiones interminables y de un verbalismo a menudo abstracto y demagógico. Se pasó de la "fuerza de la razón" a la "razón de la fuerza", con una aversión contra toda forma de poder constituido y contra la vida privada, a la que se contemplaba como un estadio arcaico y superado. 
Dichos movimientos trataron de dar respuesta a algunos de los problemas y novedades más candentes, como la independencia económica de la mujer, el dominio de su misma fecundidad y su acceso a la educación universitaria; el fomento del sentido crítico, que alimentó una ola antinormativa, con efectos demoledores en muchos sectores de la sociedad; la conciencia de encontrarse en un cambio de época, donde el pasado debía ser rechazado, para construir un futuro totalmente nuevo.

La Iglesia se vio afectada tanto por el cambio nacido impetuosamente a raíz del Concilio, como por el desarrollado en la sociedad. El «Pueblo de Dios» no fue sólo una de las categorías centrales de la LG, sino de todo el Concilio. La Iglesia no fue percibida más como una jerarquía, sino como un pueblo que camina en la historia, congregado por la Trinidad, para ser Sacramento de la unión del hombre con Dios y de los hombres entre sí y para anunciar las maravillas de Dios con los hombres, escudriñando la acción del Espíritu en medio de los hechos históricos.

Un Pueblo que participa del don profético de Cristo, difundiendo su vivo testimonio, por la vida de fe y de caridad, gracias al Espíritu Santo, quien no sólo santifica y dirige al Pueblo de Dios por los Sacramentos y los ministerios, sino que también reparte gracias especiales entre los fieles, en vistas a la realización de una gran variedad de obras para la renovación y una más amplia edificación de la Iglesia (LG 12).

Una Iglesia, que como diría Pablo VI, encontraría en el diálogo un intento de reconciliación con el mundo moderno ${ }^{4}$, confiando en la innata disposición del hombre al bien y con la convicción de que la época moderna no sólo está empapada de prevaricaciones, sino que es también el lugar de la acción de la Providencia. Particularmente importante fue el impulso dado al ecumenismo, que en esta fase inicial, se centró especialmente en los protestantes, coherederos con los católicos, de la modernidad y la racio-

\footnotetext{
4 "La Iglesia debe ir hacia el diálogo con el mundo en que le toca vivir. La Iglesia se hace palabra; la Iglesia se hace mensaje; la Iglesia se hace coloquio...Y no podemos hacerlo de otro modo, convencidos de que el diálogo debe caracterizar nuestro oficio apostólico, como herederos que somos de un estilo, de una norma pastoral que nos ha sido transmitida por nuestros Predecesores del siglo pasado, comenzando por el grande y sabio León XIII, que casi personifica la figura evangélica del escriba prudente, que como un padre de familia saca de su tesoro cosas antiguas y nuevas, emprendía majestuosamente el ejercicio del magisterio católico haciendo objeto de su riquísima enseñanza los problemas de nuestro tiempo considerados a la luz de la palabra de Cristo... ¿No se ha querido dar al mismo Concilio, y con toda razón, un fin pastoral, dirigido totalmente a la inserción del mensaje cristiano en la corriente de pensamiento, de palabra, de cultura, de costumbres, de tendencias de la humanidad, tal como hoy vive y se agita sobre la faz de la tierra? Antes de convertirlo, más aún, para convertirlo, el mundo necesita que nos acerquemos a él y que le hablemos" (Ecclesiam suam 27 ).
} 
nalidad occidental. Así, la gran literatura protestante invadió las librerías y las bibliotecas católicas.

Por su parte, la vida religiosa trató de llevar a la práctica la renovación deseada por el Concilio, partiendo del adjetivo evangélico, que en la mayoría de los casos fue tomado como sinónimo de pobreza, sencillez y antitriunfalismo, de promoción de estructuras más simples y más eficaces, que relativizaron muchas de las tradiciones que hasta entonces se vieron como patrimonio intocable. Sustentándose en la intrínseca complementariedad que ha de existir entre la Biblia y la vida, de tal forma que el Evangelio se convirtió en la norma suprema de una vida religiosa centrada en la escucha y en la obediencia a la Palabra de Dios, confrontada con la vida cotidiana y expresada en la celebración litúrgica de los divinos misterios.

Se pasó de una cierta "fuga mundi", al descubrimiento de los elementos positivos de un mundo, que debe ser conducido hacia el Evangelio, pero que también posee cosas buenas que enseñar. Para numerosos religiosos la apertura tuvo como consecuencia no sólo el salir al mundo con un nuevo estilo de testimonio y misión, sino también hacer entrar al mundo dentro de las paredes de la vida religiosa, poniendo la centralidad no en la ascética y el combate espiritual, sino en el empeño del "ser por los otros".

$\mathrm{Al}$ mismo tiempo se incrementó el respeto hacia el ser humano, de tal forma que el religioso no fue contemplado sólo como una fuerza apostólica, sino como una persona a la que escuchar y con la que dialogar, para tener presentes sus necesidades y aspiraciones y valorar mejor sus dones en vista de la misión.

Cada vez fue más patente la crisis de numerosas obras, producida por un Estado, que bajo la iniciativa de poder solucionar él solo, los problemas sociales, se adentró cada vez más en el área de la salud, de la educación y de la asistencia social, campos tradicionalmente típicos de la vida religiosa. Ello provocó que las obras de los religiosos realizadas en el pasado fueran contempladas por àlgunos como una "suplencia" de la intervención pública, negando así su identidad como una expresión originaria de la creatividad y de la capacidad humanizadora de la caridad cristiana.

5 "Descubrir y discernir la validez de lo nuevo que está naciendo entre nosotros. Acoger y promover esa novedad como don de Dios y compromiso. Fortalecer la espiritualidad y misión compartidas con el Pueblo de Dios y la comunión y solidaridad entre la vida consagrada femenina y masculina. Comprometernos a compartir la pasión por Cristo y por la humanidad en nuevos contextos; la vida consagrada está urgida a cultivar y privilegiar el apasionamiento por Dios y por el ser humano (VC 84). Ser la voz de la vida consagrada para la vida consagrada" (Pasión por Cristo, pasión por la humanidad. Congreso internacional de la vida consagrada, Roma, 23-27 noviembre 2004, 29). 
Por los motivos anteriores, la comunidad religiosa tradicional entró en crisis, acompañada por la consiguiente búsqueda de nuevas soluciones, que tenían en común el deseo de tejer relaciones interpersonales más estrechas, para dar lugar a una hermandad más cordial. Se crearon pequeñas comunidades con el objetivo de conseguir un mayor testimonio de sencillez evangélica, por necesidad de apostolado, o por una búsqueda de intimidad que no era posible alcanzar en el anonimato de los grandes aglomerados. La Exhortación apostólica Evangelica Testificatio (ET), en su número 40, advertiría en la década de los 70 , contra el entusiasmo y la excesiva confianza depositada en las pequeñas comunidades, subrayando sus límites y dificultades.

Se estudiaron las bases teológicas, bíblicas, antropológicas y psicosociológicas de la comunidad, iniciando experiencias comunitarias en las que fuese posible verificar en la práctica, el ideal teórico de comunidad y abrir así el cauce a una reflexión más enriquecedora para la vida.

La comunidad religiosa fue presentada como un fermento de renovación, de dinamismo interior, de creatividad y de respuesta a las instancias del tiempo y en el tiempo, que están inmersas en el corazón de la historia. Como el lugar y el clima en el que los religiosos pueden encontrar su identidad, de la que han de partir para emprender las nuevas elecciones, llenas de coraje, que se imponen en una época caracterizada por tendencias que parecen de signo contrastante. Por un lado, la era de la autonomía y de las comunicaciones y por otra, de la unidad y de la incomunicabilidad.

Se invitó a la comunidad religiosa a reencontrar sus raíces evangélicas, es decir aquel deseo primigenio de poder estar siempre con Jesús, penetrar en su intimidad, ponerse incondicionalmente a su seguimiento bajo el ejemplo de los discípulos del Evangelio y poder repetir la experiencia de unidad que poseían aquéllos, en torno al Señor resucitado, reviviendo así el "cor unum et anima una" de la primera comunidad cristiana.

Reencontrar la comunidad significaba volver a descubrir sus raíces primigenias, basadas en la llamada de la Palabra creadora y eficaz, que se recrea revelando en el tiempo el proyecto eterno de elección y opera lo que enuncia. Una invitación incondicional unida al acto de fe en la persona de Cristo, reconociéndolo como el Hijo enviado del Padre, quien otorga el significado a la propia vida e implica una unión a Él y a su misión, descentrándose de uno mismo, para moverse en torno a Él, compartiendo su destino, hasta dar la vida con Él.

Significaba reencontrar al hombre como ser en relación, yendo a la fuente misma de la unidad, para indicar después el camino que hay que seguir en orden a responder a las exigencias del hoy, en relación al sentido 
de la persona y a su sed de establecer relaciones auténticas. Era sentirse enviados por Cristo al mundo entero para anunciar la Buena Nueva, reproduciendo la vida de unión que los apóstoles habían instituido en Jerusalén, para dedicarse totalmente con el Hijo, a la causa del Reino, en comunión con el Padré.

Para ello se exhortaba a convertir la vida en una obediencia, es decir, en una respuesta personal a Dios, experimentando el éxodo, para poder acompañar a los que se encuentran en desiertos de soledad y sufrimiento. Una obediencia que recuerda al Dios que sueña con nosotros, ya desde el instante mismo de nuestra concepción y que invita al religioso a dar vida y a convertirse en una forma concreta con la que Dios se da a cada hombre ${ }^{7}$.

Por eso, la misión de la vida religiosa no es una misión particular, sino sencillamente la misión misma de la Iglesia, peculiarizada en unos determinados ministerios y estilos de vida, que dependen fundamentalmente de la imagen de Jesús que se tenga. No se confunde con un encargo, una encomienda jurídica, o una simple tarea profesional, para la que se requieren dotes especiales, sino que se caracteriza por su finalidad primariamente teológica: glorificar a Dios entre los hombres, con la palabra y la vida de la comunidad, uniendo misión, gloria y glorificación. Testimoniar el amor de Jesús en medio del mundo y en la Iglesia, a través de la imagen de personas que viven unidas, bajo una común vocación, a pesar de las diferencias de edad, pensamiento, razas y culturas.

La filiación no es una experiencia adormecedora, sino inquietante, aventurada y sumamente arriesgada, que hace pasar por el destierro, la expatriación misionera y la dolorosa nostalgia de nuestros orígenes. Conlleva el evangelizar o testimoniar la Palabra, santificar la realidad con el Espíritu de Cristo y conducir a la comunidad y al mundo hacia Cristo. Todo ello a través de la relación íntima con Cristo, la generosidad evangélica en

6 "La vida de la comunidad religiosa no es replegamiento narcisista sobre sí misma, sino apertura hacia el exterior para comunicar a todos el don recibido y acoger a todos en la dinámica de la unidad. La vida de la comunidad se expresa ahora en servicio, en diaconia, testimonio, anuncio. El Resucitado que vive en ella, comunicándole su propio Espíritu, la hace testimonio de la resurrección. Como el Resucitado envía a la comunidad al mundo entero y como el Espíritu conduce a la primera comunidad cristiana fuera del cenáculo, así toda comunidad religiosa, es transformada por el Resucitado en auténtica comunidad pneumatológica, es conducida hacia el mundo: es intrínsecamente, por naturaleza, apostólica" (F. CIARDI, Koinonia, itinerario teológico espiritual de la comunidad religiosa, 251).

7 "Porque soy de Dios, y no de mí, debo ser para los demás... la realización de ese ser ha de desplegarse en la línea del don, disposición de amor. Desde él cabe decir con entera verdad que el hombre es una manera finita de ser Dios" (J. L. RUIZ DE LA PEÑA, Imagen de Dios, Santander 1988, 183). 
el seguimiento del mismo, la disponibilidad misionera y la fraternidad como signo eficaz de evangelización, mediante el compartir. Este último se presenta como el modelo teológico que expresa la realidad trinitaria en la que cada uno se da y se recibe del otro y todo es de todos, en la inconfundible originalidad de cada uno. Pero también como el modelo de la encarnación gozosa del Hijo, que nos concede su divinidad al asumir nuestra humanidad. Así como el modelo eclesiológico en el que se sustenta la Iglesia comunidad y comunión ${ }^{8}$.

Función de las comunidades religiosas es estimular a los creyentes hacia la misión, con su género de vida testimonial. Una comunidad religiosa que no sea capaz de hacer más misioneros a sus hermanos, no está cumpliendo su función en el Pueblo de Dios. A su vez, una condición indispensable para la misión es la experiencia personal y comunitaria del Señor resucitado, que sale al encuentro del hombre y suscita en él un novedoso estilo de vida, un nuevo horizonte de existencia, que radicaliza su misión, comprendida ahora cristológicamente 9 . Se establece así una trilogía, que manifiesta una sola realidad: vocación, consagración y misión. Son tres momentos de un único acontecimiento espiritual: el Padre llama, el Espíritu consagra y el Hijo envía. Y este acontecimiento es ante todo, eclesial, de tal modo que hay vocación, consagración y misión individual, porque previamente se dan comunitariamente.

La comunicación del Evangelio ha de realizarse simultáneamente a un triple nivel; cognoscitivo, que indica lo que hay que creer; constitutivo, que muestra lo que hay que llegar a ser, haciendo fructificar el don del amor, en una comunidad cristiana abierta a la universalidad; efectivo, en

8 "La dimensión apostólica y de diakonia de las comunidades religiosas, diferente según los diversos carismas, se coloca igualmente en la línea de la salida de la Trinidad de sí misma, en su éxtasis de amor con el cual se da y se pone al servicio del hombre. La comunidad se abre a su vez y continuando la misión confiada por el Padre al Hijo y cumplida en el Espíritu, se da en la propia típica ministerialidad, para llevar a todo el hombre y a todos los hombres hacia la realización de su vocación que es la de vivir en la Trinidad. Pero es sobre todo en torno a la realidad de la comunidad en su dimensión de koinonia, que la referencia a la Trinidad se hace más urgente y más fecundos los resultados. Por tanto, podemos partir, en esta reflexión, del Vaticano II, donde la Iglesia ha expresado con más profunda conciencia la propia referencia a la Trinidad" (F. CIARDI, Koinonia..., 207).

9 "Jesús llama al seguimiento con vistas a la instauración de ese reino o, lo que es lo mismo, con el objeto de crear una comunidad nueva, distinta tanto del esoterismo elitista del modelo qumránico como del activismo agresivo del modelo zelota. El rasgo distintivo de esa comunidad, con la que amanece el verdadero reino, es la invocación de Dios como Abbá, el reconocimiento de la propia filiación y el establecimiento de la fraternidad interhumana" (J. L. RUIZ DE LA PEÑA, El don de Dios: antropología teológica especial, Santander 1991², 246-247). 
cuanto que orienta el servicio cristiano en medio de la sociedad humana, para hacer visible el Reino de Dios.

Puede comunicar la Palabra aquella comunidad que ha sido agraciada por la comprensión cognoscitiva de la misma. No es un mero ejercicio intelectual sobre un texto, un discurso o unas ideas, sino que incluye sobre todo un acercamiento personal y comunitario a la verdad del designio de Dios sobre el mundo ${ }^{10}$. Es un momento integrante en el acontecer de la automanifestación de Dios al hombre, que supone el manifestar públicamente, lo revelado por Dios a través de la mediación humana. Pero llega a ser auténtico conocimiento cuando al anuncio externo de la Palabra, corresponde la iluminación interior producida por el Espíritu.

Sin embargo, a pesar de la fuerte fundamentación comunitaria, en la segunda mitad de los años 60 se incrementó el número de salidas dentro de la vida religiosa, debido en gran parte a la liberación que supuso el Concilio de aquellas barreras, que años atrás, amenazaron con aislar de la sociedad a dicho género de vida. Pero una liberación que no siempre fue correctamente interpretada y vivida, originando en muchos casos el desmoronamiento de la disciplina y la pérdida de las motivaciones profundas, bajo un humanismo cada vez más secularizador.

Las dificultades en el campo apostólico se acentuaban ante la inesperada bajada del interés religioso de la sociedad y su orientación hacia modelos cada vez más sustraídos de la impostación religiosa de la vida. Así como el influjo de una insensibilidad hacia la historia, del detrimento de la fidelidad como valor y del exceso de un idealismo, que rompió el equilibrio entre lo ideal y lo real, decantándose hacia movimientos como la New Age.

La ciencia sustrajo a la filosofía y a la religión las preguntas que después se vería obligada a devolver. La ruptura entre razón y fe impidió la construcción de una síntesis creativa entre Evangelio y vida, que fuese capaz de dotar de un alma a la sociedad moderna. Se convirtió sin duda en el drama de una época, que parecía saber mucho sobre el hombre, pero que sin embargo, conocía poco de aquel ser, que esencialmente tiene que ir haciéndose.

Se hizo patente el aumento del número de los no practicantes, los cuales se esforzaban por justificar su posición, en nombre de una religión inte-

10 "La necesidad del testimonio está unido también a la naturaleza misma de la buena noticia. Ésta, antes de ser verdad, es vida y la vida se comunica a través de la vida, en el misterio mismo. Sólo en la medida en que se es capaz de vivir el misterio de Cristo, su palabra, su relación de amor y de donación total al Padre, la cruz, el anuncio de su misterio será creíble. El anuncio de Cristo presupone siempre la experiencia de Cristo" (F. CIARDI, Koinonia..., 255). 
rior, de una autonomía o de una autenticidad personal, como en la década de los 70 señalaría el documento Evangelii Nuntiandi (EN), en su número 56. Una religión, en parte heredada de un pueblo, que en el pasado careció de medios adecuados para expresar su vida de fe y contó con un vocabulario religioso inaccesible a su mentalidad.

Tras desfigurar la imagen de Dios, para conformarlo a los objetivos personales de cada hombre, se dio paso al ateísmo, al laicismo, o la búsqueda incierta de una nueva religiosidad, donde estaban en desacuerdo el hombre y el Dios que le era presentado. El ateísmo alimentado por la ausencia de reflexión; que desmiente con los hechos una fe profesada por las palabras; que llega a la conclusión de la imposibilidad de probar que Dios exista; o que afirma que Dios no existe y hace de su no existencia el fundamento del humanismo. El laicismo, que se caracteriza por su desconfianza hacia las impostaciones metafísicas, negando la presencia divina en el mundo, bajo el aparente silencio de Dios.

Respecto a dichas dificultades resultaron fundamentales la Carta apostólica Ecclesiae Sanctae (ES), que animó a promover la renovación de la vida religiosa, con prudencia, pero también con prisa; la Instrucción Renovationis Causam (RC), que trató de la adecuación de la formación a las necesidades de los tiempos; posteriormente, la Exhortación apostólica Evangelica Testificatio (ET), que considerada la «carta magna» de la vida religiosa, exhortó a una reformulación de los valores morales, que sin perder de vista el Evangelio, pasase de la adaptación exterior a la renovación interior; los nuevos Rituales litúrgicos de la profesión religiosa y de la consagración de las vírgenes.

\section{B. La década de los 70}

Con el año 1973 se inició una nueva década marcada por la crisis petrolífera y su consecuente desmoronamiento de la creencia mantenida años atrás respecto a la posibilidad de un desarrollo sin fin. La conciencia de una limitación de los recursos del planeta acentuó la reflexión ecológica y maduró la crisis económica, a la que se trató de responder desde el mito del colectivo, es decir, desde la convicción de la necesidad de la corresponsabilidad y de la participación de todos en la gestión de todo, dando prioridad a lo colectivo respecto a lo personal.

En cuanto a la Iglesia se pasó de la unidad entendida como uniformidad, a una fragmentación de posiciones que cambiaron sensiblemente el cuadro eclesial y la misma idea de unidad. Así lo manifestaron el auge que 
alcanzó la iglesia local, a través de una creciente conciencia de su dignidad teológica y de su misión, así como los movimientos que fueron surgiendo en la Iglesia, hasta convertirse en un claro exponente de su viveza. Mientras que en América latina se caracterizaron por el empeño de la liberación, en Europa se dividieron entre los orientados a un empeño típicamente eclesial y los que se decantaban hacia un claro empeño político.

La misión de la Iglesia pasó a ser considerada como misión de salvación en el mundo y del mundo, para la liberación total del hombre y de todo hombre, rompiendo con el idealismo de las anteriores corrientes teológicas, en torno a la conciencia individual y racional, para adoptar como regla la transformación de la sociedad. Ya en 1967, la Carta Encíclica Populorum Progressio (PP), atenta a los factores culturales, solicitó la colaboración de todos, especialmente de los países con mayor estabilidad económica, para favorecer el desarrollo de los más pobres.

La vida religiosa osciló entre la Iglesia-pobre, que predica la pobreza absoluta como condición para desarrollar la acción apostólica, y la Iglesia de los pobres, que prefiere hablar de atención y amor a los mismos. Se crearon así tensiones dentro de este género de vida, causadas por la diferente interpretación dada a la pobreza y a la relación entre evangelización y promoción humana, sus implicaciones en las grandes elecciones y en los objetivos apostólicos y su estilo evangélico de presencia.

En torno a dichas problemáticas se solicitó la participación de todos los religiosos a través de los Capítulos especiales. Éstos constituyeron un hecho inédito en la vida religiosa, que permitió la iluminación de las nuevas Constituciones, por medio de la recepción de la gran teología del Concilio, así como la búsqueda de la identidad del Instituto, en torno al propio fundador y a la historia de la fundación. En las nuevas Constituciones de cada Instituto se fue perfilando su identidad, ubicación y misión en la Iglesia, así como su utilidad en la sociedad, acogiendo el Concilio (aspecto teológico), expresando la tradición espiritual del Instituto (aspecto carismático) y conteniendo la normativa del nuevo Código (aspecto jurídico).

La teología del carisma ${ }^{11}$ nació de una reflexión histórico-existencial, de tipo inductivo, en sintonía con las exigencias del tiempo. Pero también

11 "El término carisma es poco usado en el Nuevo Testamento: 17 veces, todas en Pablo (de las cuales 14 en Cor y Rom), excepto en 1 Pe 4, 10. Mirando el ámbito de la utilización del término se puede deducir que él (el término evidentemente, no la realidad) no fuese de primera importancia, de lo contrario hubiese sido utilizado con mayor frecuencia. De hecho, no se encuentra en los Evangelios. El uso de la palabra carisma era por tanto rara o inexistente en la predicación primitiva. No por esto se puede decir que la actividad del Espíritu Santo en la comunidad primitiva no fuese un hecho real y no se manifestase en modo vital; 
de una reflexión teológico-espiritual, que partiendo de la historia y de la vivencia de cada Instituto, lo interpretó no sólo como la historia de la intuición de un fundador, sino como el fruto de una intervención del Espíritu que obra conforme al bien de su Iglesia. Se combinó el valor de la fidelidad, ante lo que posee una validez perenne en el carisma, con el valor del dinamismo, ante su historicidad, y por lo tanto la posibilidad de reinterpretación del mismo ${ }^{12}$.

Se presentó al carisma del fundador como el contenido de su experiencia, que originada por una inspiración sobrenatural y guiada por la comprensión existencial del misterio de Cristo ${ }^{13}$, lleva a delinear la fisionomía de una obra que se expresa como un servicio a la Iglesia y a la sociedad y la respuesta vital a una determinada situación histórica.

Se consideró al carisma de fundador como el don particular que es concedido por el Espíritu a una persona, para que en la Iglesia se dé origen a una familia religiosa. El fundador propone una exégesis viviente del Evangelio, de cuya interpretación es garante la Iglesia, y una particular vía de santidad, poniéndose como guía de un grupo de fieles, que reúne en torno a sí con un vínculo estable, que va transmitiendo a sus sucesores ${ }^{14}$.

De aquí se desprende no sólo el compromiso de evangelizar, sino de estar disponibles y tener la libertad interior para dejarse evangelizar, como

basta confrontar el primer escrito neotestamentario: "no malgastad el Espíritu, no despreciad las profecías $(1$ Tes 5,19$)$. Más allá de ello, el problema del vocabulario ha interesado exclusivamente a la Iglesia de Corintio y por un período así de breve (57-59). La cuestión del término ya no se pone más en la segunda carta. En la carta a los Romanos su presencia se explica como reminiscencia de lo sucedido en Corintio. Se puede concluir con Wambacq, que fue Pablo quien utilizó la palabra para expresar las manifestaciones del Espíritu Santo en la Iglesia. Después de la experiencia de Corinto, donde la palabra comenzaba a tomar un signifícado equívoco: sabiduría, ciencia, hablar en lenguas, parece que de propósito la haya utilizado lo menos posible (B. N. WAMBACQ, "Le mot charisme", en Nouvelle Revue Théologique, 107 (1975), 345-355).

12 "El fundador es como el terreno en el cual es plantada una semilla. No sabe cómo será el árbol que nacerá, pero acogiéndolo con plena disponibilidad y alimentándolo constantemente, permite su desarrollo. Conforme el árbol crece conquista proporciones y formas nuevas, pero sin traicionar la naturaleza escondida en la semilla, sino llevándola a la madurez y a su plena realización" (F. CIARDI, I Fondatori uomini dello Spirito. Per una teologia del carisma di Fondatore, Roma 1982, 119).

13 "En la experiencia de los fundadores encontramos a menudo la afirmación de una total ignorancia en relación a la obra que emprender. La inspiración fundamental ha sido una gracia iluminativa particular, que les ha hecho percibir una determinada forma de vida, un objetivo por alcanzar. Pero no se trata de un plano detallado en los particulares. Los fundadores ni siquiera suelen conocer el camino que recorrer para su realización. La inspiración tiene por objeto los contenidos ideales más que determinadas estructuras o formas expresivas de tales contenidos" (F. CIARDI, I Fondatori uomini dello Spirito..., 93).

${ }^{14}$ Cf. F. JUBERÍAS, El fundador y su familia religiosa, Madrid 1978. 
condición indispensable para revitalizar los carismas y abrir nuevas perspectivas en vistas de una nueva comprensión del don recibido. De este modo se constituyen personas y comunidades maduras en la fe y capacitadas para responder a las nuevas situaciones culturales y sociales.

No será la aventura de una sola persona, sino de cada uno de los grupos que componen la comunidad cristiana, los cuales han de manifestarse no como los propietarios del mensaje anunciado, sino como instrumentos y servidores del mismo, según sus carismas y su carácter ministerial. Los centros privilegiados para el anuncio han de ser los lugares donde se manifieste una mayor ausencia y sed de Dios, dando a conocer a la persona de Jesús, con unas estrategias que mejoren la calidad de las relaciones entre los hombres y preserven al Evangelio de falsas interpretaciones.

Sin embargo, la ilusión de algunos religiosos ante el redescubrimiento del propio carisma quedaba confrontada con el escepticismo de aquellos otros, que no sabían cómo orientarse en un momento de convulsión, de cambios de pensamiento y de costumbres y de abandonos masivos entre los miembros de la vida religiosa. A su vez el desplazamiento hacia el Sur del planeta, debido al descenso de las vocaciones, conduciría a la elaboración de nuevas formas dentro de dicho género de vida, que hablasen en términos de una creciente inculturación.

El documento Mutuae Relationes (MR) ahondó en la temática de la identidad de la vida religiosa dentro de la eclesiología de comunión, reconociendo la naturaleza carismática de los diferentes Institutos y haciendo hincapié en una fidelidad dinámica a los orígenes. Ante la evolución cultural y la renovación eclesial vigentes en el momento, se hacía imprescindible asegurar el conocimiento exacto de la identidad de cada Instituto, de tal manera que sus miembros, conscientes de su estilo particular carismático, de santificación y apostolado, evitasen el insertarse de manera vaga y ambigua en la vida de la Iglesia.

De ahí la exhortación dirigida a los religiosos a vivir, custodiar, profundizar y desarrollar constantemente su identidad carismática, en sintonía con el Cuerpo de Cristo, haciendo de su consagración un modo especial de participación en la naturaleza sacramental del Pueblo de Dios, bajo el objetivo de testimoniar visiblemente el misterio insondable de Cristo, el siempre obediente a la voluntad del Padre que le envió (MR 10-11).

Las reflexiones teológicas en torno a la comunidad y el carisma, en medio de un ambiente inquieto $\mathrm{y}$, hasta hostil, aportaron muchos elementos positivos de reconstrucción e identificación de la vida religiosa. Se reconoció la urgencia de potenciar auténticas relaciones interpersonales en la oración y apostolado, pero quedaron asimismo, al descubierto, deficiencias 
graves, nacidas de planteamientos unilaterales, como un cierto narcisismo comunitario o la pérdida del sentido congregacional de pertenencia.

La preocupación por la comunidad y la propia identidad carismática fue tan obsesiva que en muchas ocasiones se perdió de vista el apostolado de la comunidad y del Instituto y se abandonó a las grandes masas eclesiales y congregacionales. Daba la impresión de que la comunidad abría sus puertas a los más celosos cumplidores y que, por el contrario, se convertía en un foco de angustia, para todos aquellos que eran conscientes de la imposibilidad de llevar a la práctica aquello que los documentos capitulares y las nuevas Constituciones renovadas pedían al respecto.

Se detectó en la Iglesia una crisis de misión en el mundo contemporáneo, como si se hubiera replegado y hubiera perdido una de sus características más inquietantes; el impulso misionero. De este modo, fue preciso que el Espíritu llevara adelante el proceso de renovación abriendo una nueva etapa, no exactamente delimitable, pero que como punto de referencia, podría partir del documento Evangelii Nuntiandi y del Sínodo de 1974.

Se intentó que el Concilio penetrase en el círculo de la comunidad eclesial, revitalizando la importancia de los elementos de evangelización que pudiese aportar el pueblo, acentuando los aspectos culturales de cada comunidad humana y propagando la inculturización teórica y práctica de la fe.

Poco a poco empezó a renacer la eclesiología del Pueblo de Dios, integrando todos los valores populares en la visión sociológica y teológica de una Iglesia, que ya empezaba a sentirse más misionera, no para destruir sino para acoger e integrar, no para implantar sino para hacer surgir y no para colonizar sino para encarnarse.

Para ello la Iglesia precisaba de una doble fidelidad. En primer lugar, al mensaje, evangelizando siendo cristiana, es decir eclipsándose delante de Dios, propiciando la unión del hombre al Salvador y teniendo en cuenta que el Espíritu, no sólo garantiza la autenticidad del anuncio, sino también la novedad de su acogida. En segundo lugar, a los hombres, no sintiéndose más divina que el Hijo encarnado, sino haciéndose presente en las estructuras creadas por la socialización y situándose de la parte del hombre frente a Dios, a un nivel antropológico (unidad del hombre), teológico (relación entre Creación y Redención) y evangélico (totalidad de los valores humanos redimidos en el amor).

En este contexto comenzó a repetirse cada vez más la palabra misión, entendida como una auténtica categoría teológica que sirve de raíz a la única misión de la Iglesia, desplegada en su variada gama de actividades, como la actividad pastoral con los católicos, la actividad ecuménica con los cristianos no católicos y la actividad misionera con los no cristianos. 
En sentido teológico se emplea la categoría de misión en el tratado de la Trinidad, refiriéndose a las procesiones inmanentes que existen entre las personas divinas y que representan las procesiones eternas en las procesiones temporales, como la encarnación del Verbo o la misión del Espíritu Santo ${ }^{15}$.

En cristología, la reflexión se centra en torno a la misión de Jesús, como el Enviado del Padre, quien en cumplimiento de la voluntad de Éste, inauguró en la tierra el Reino de los cielos, nos reveló su misterio y efectuó la redención con su obediencia (LG 3). Asimismo trata de la misión de los Apóstoles, elegidos por Jesús, para que viviesen con Él y ser enviados a predicar el Reino de Dios, confiriéndoles el encargo de enseñar, santificar y regir en su mismo nombre y autoridad, misión en la que fueron confirmados plenamente el día de Pentecostés. Para que con la potestad que les entregaba, hiciesen discípulos suyos a todos los pueblos, los santificasen y gobernasen y así extendiesen y apacentasen a la Iglesia, sirviéndola, bajo la dirección del Señor, hasta la consumación de los siglos (LG 19).

En eclesiología se habla de la misión que la Iglesia confía a ciertos hombres dentro de su dinámica comunitaria y organizativa ${ }^{16}$. Una Iglesia, que enriquecida con los dones de Cristo, su Fundador, y observando fielmente sus preceptos de caridad, humildad y abnegación, recibe la misión de anunciar el Reino de Dios y de establecerlo en medio de la humanidad. Constituye en la tierra el germen y el principio de dicho Reino, siendo un sacramento de la íntima unión con Dios y de la unidad de todo el género humano (LG 1 y 5).

$\mathrm{Su}$ diversidad de ministerios, se integran en la unidad de misión de cada uno de sus miembros ${ }^{17}$, que ligados entre sí, permiten el crecimiento y la perfección en la caridad $(E f ., 4,15-16)$ de todo el Cuerpo, que es la Igle-

15 "Participar en la vida trinitaria quiere decir participar en su misma dinámica de amor. La misión del Hijo prolonga en la historia la generación eterna, así como la misión del Espíritu prolonga y manifiesta su eterna inspiración. El Vaticano II ha deseado mostrar en la Iglesia la prolongación de las procesiones divinas del Verbo y del Espíritu, casi el desarrollo histórico del misterio trinitario. Las procesiones divinas y eternas del Hijo y del Espíritu aparecen como las condiciones de posibilidad, los modelos y las causas eternas de la Iglesia, como cumplimiento de la entera creación, llamada a ser eternamente integrada" (F. CIARDI, Koinonia..., 215).

${ }^{16}$ Cf. S. DIANICH, "La missione della chiesa nella teologia recente", en ATI, Coscienza e missione di chiesa. Atti del VII Congresso Nazionale, Cittadella 1977.

17 "El hombre se comprende a sí mismo como enviado con una tarea a la historia, a una historia concreta de lugar y de tiempo, para llevar a cabo un proyecto propio, aún cuando esté inserto dentro de otro comunitario y que a pesar de su pequeñez o de su grandeza, es sin embargo, un proyecto específicamente propio, emerge de su libertad y está ordenado a densificarla y acrecerla" (O. GONZÁLEZ DE CARDEDAL, Ética y Religión, Madrid 1977, 100). 
sia, cuya Cabeza es Cristo. Así por ejemplo, los laicos, hechos partícipes del ministerio sacerdotal, profético y real de Cristo, ejercen el apostolado con su trabajo para la evangelización y santificación de los hombres y para la función y el desempeño de los negocios temporales, llevado a cabo como fermento evangélico en medio del mundo, hasta convertirse en un claro testimonio de Cristo, que trae la salvación de los hombres (AA 2). O los Pastores, quienes tienen como función apacentar de tal modo a los fieles y reconocer sus servicios y carismas, que todos cooperen unánimemente en la obra común de la misión salvífica de la Iglesia (LG 30).

En Derecho Canónico, misión es el acto de la autoridad eclesiástica por el que se da a alguien el encargo o el permiso de predicar la doctrina de la Iglesia y ejercer la actividad docente que sigue al acto del envío (Cann. 781-792).

Sin embargo, el término misión, en su sentido teológico más estricto, aparece como correlativo al término apostolado. Si en un principio prevaleció el carácter eminentemente pasivo del vocablo ser enviado, posteriormente se pondría el centro de atención no en el enviado, sino en la persona que envía, en este caso Dios. Se pone de manifiesto cómo el término "apostolos" en el NT es un vocablo típico de la lexicografía paulina y aparece en conexión con la misión, identificando al apóstol con el misionero ${ }^{18} \mathrm{e}$ identificando a la misión con la acción evangelizadora de la Iglesia entre las poblaciones que no conocen todavía el Evangelio.

Se originó así una especie de teología de la misión, que se inició ya germinalmente con la constitución dogmática LG, en el número 17, y continuó con el Decreto conciliar Ad Gentes (AG), creciendo como a la sombra de la teología del apostolado ${ }^{19}$. En dicho número se afirmó que la Iglesia ha recibido de los Apóstoles el mandato de Cristo de anunciar a toda la tierra

${ }^{18}$ Cf. T. CITRINI, "Apostolado", en Dizionario Teologico Interdisciplinare I, Torino 1977, 401-404.

19 "El término missio aparece en los documentos conciliares 103 veces; es uno de los vocablos que el Concilio ha elevado a nivel de categoría (hago caso omiso de su empleo en plural missiones). Su campo semántico revela una coherencia de significado en sus múltiples aplicaciones, como lúcidamente se expresó en el decreto Apostolicam Actuositatem, n. 2: "Est in Ecclesia diversitas ministerii, sed unitas missionis". El Concilio habla de la missio Christi (título de LG 3; UR 7; AA 8; 29; AG 2; 4; 5; 18; 24; 25; PO 2; 169, missio Spiritus Sancti (LG 48; DV 17; AG 2), missio Ecclesiae, en general (LG 5; 8; 36; 37; UR 16; PC 6; AA1; $2 ; 5 ; 19 ; 24 ; 29 ;$ DH 13; AG 4; 5; 6; 9; 39; 41; título del cap. 1 de PO; PO 2; 11; 14;17; GS 76), como misión religiosa (GS 11; 42), como misión salvífica (LG 30; 33; 43; AA 6; 33), como misión apostólica (LG 65; PO 2), universal (LG 1; 31; AG 20; GS 42; 58; 89; 92), como misión de todo el pueblo cristiano (LG 30; 31; GE 8). La misión de la Iglesia que especificada en los diferentes grupos, comunidades o personas: misión de las nuevas Iglesias (AG 20), de los Doce Apóstoles (LG 19; 20; CD 36; PO 10), de los obispos (LG 20; 24; 28; CD 36), de los 
la verdad salvadora, moviendo así a los oyentes a la fe y a la confesión, disponiéndolos para el Bautismo, arrancándolos de la servidumbre del error y de la idolatría e incorporándolos a Cristo, para que crezcan hasta la plenitud por la caridad hacia Él.

En el Decreto citado, se pasó de considerar a la misión como una actividad de la Iglesia, a contemplarla como la naturaleza de la misma. En efecto, AG 2 diría que la Iglesia peregrinante es misionera por su naturaleza, ya que procede de la misión del Hijo y de la misión del Espíritu Santo, según el designio de Dios Padre. Se vinculó así el término misión al significado que posee en su empleo trinitario y se hizo derivar la actividad de la Iglesia de su naturaleza misionera.

En su número 24, el documento enunció las características del misionero, un enviado que debe responder al llamamiento de Dios, movido y fortalecido por el Espíritu Santo, quien le ayuda a entrar en la vida y en la misión de Aquel que "se anonadó tomando la forma de siervo", estando dispuesto a permanecer siempre en su vocación, a renunciar a sí mismo y a sus posesiones y a "hacerse todo a todos".

A partir del Sínodo de 1974 y de la EN se siguió profundizando en la teología de la misión, desde la perspectiva de la evangelización. En el número 18 de dicho documento se resaltó cómo la acción evangelizadora de la Iglesia consiste en llevar la Buena Nueva a todos los ambientes sociales y con su influjo transformar desde dentro y renovar a la misma humanidad.

Todo este proceso logró una consolidación importantísima en el Tercer Mundo, en la tercera conferencia del episcopado latinoamericano, reunido en Puebla, del 28 de enero al 13 de febrero de 1979. En ella se partió de Cristo como el enviado del Padre, quien permanece en la humanidad, animando con su Espíritu a la Iglesia y ofreciendo al hombre de hoy su palabra y su vida, para conducirlo a su liberación integral y revelarle la verdadera grandeza de su realidad más íntima (documento de Puebla, n. 169).

La Iglesia, misterio de comunión y Pueblo de Dios, se pone al servicio de los hombres, siendo evangelizada y evangelizando (documento de Puebla, n. 166). De este modo testimonia al Dios revelado en Cristo por el

presbíteros (LG 28; AG 39; PO 1; 7; PO 10;11;16; 18), misión canónica (nota explicativa a la LG 2, 24; AA 25; AG 17; PO 7), misión de los diáconos (LG 41), de los religiosos (LG 43; PC 6; AG 18), de los laicos (LG 30; 33; 34; AA 1; 2; 5; 13; 29; 33; AG 21; 41; PO 9), misión de la familia (AA 11; GS 50; 52), misión de las asociaciones apostólicas (AA 19). Tal lenguaje sobre la misión se hace frecuente en documentos posteriores del Magisterio, Evangelica Testificatio, Evangelii Nuntiandi, Mutuae Relationes, Los Religiosos, la contemplación y la promoción humana; Documentos de Medellín y Puebla (Cf. J.C.R. GARCÍA PAREDES, Misión de la vida religiosa, Madrid 1982, 31). 
Espíritu y anuncia la buena nueva de Jesucristo mediante la Palabra, la cual suscita la fe, que es manifestación de la vida de Jesucristo en cada hombre, a través de la conversión, la entrega a Él y la participación en su muerte (documento de Puebla, n. 358).

La evangelización se centraliza en la redención integral de las culturas, mediante el diálogo respetuoso, el discernimiento que corrige y transforma y la consolidación y el perfeccionamiento; en la promoción de la dignidad del hombre y la liberación de todas sus esclavitudes e idolatrías, a través de la transformación de la Palabra en vida, capaz de fortalecer el corazón de los hombres, edificar a la comunidad humana y manifestar una actitud operante y de amor preferencial por los pobres; en la necesidad de hacer penetrar el vigor del Evangelio hasta las fuentes inspiradoras y los modelos de la vida social y política, mediante la fidelidad a la presencia y a la acción del Espíritu en medio de los pueblos y las culturas, como expresión de las legítimas aspiraciones de los hombres (documento de Puebla, nn. 343-345). Sin olvidar que los elementos culturales deben basarse en la verdad que es Cristo, de quien recibirán una huella de futuro, que los empujará hacia su dinamización. Es preciso extraerlos creativamente y con lenguaje sencillo, accesible y lleno de sentido para el hombre de la calle, de manera que el Evangelio presente una línea de evolución, desarrollo y despliegue dentro de la cultura.

Con la nueva concepción misionera y evangelizadora de la Iglesia se correspondió el redescubrimiento de la misión de los Institutos religiosos, de la función que les ha encomendado la historia y la aceptación de las tareas que se derivan de ella.

Como en todo proyecto de consagración podemos observar dos movimientos; uno descendente y otro ascendente ${ }^{20}$. Con el primero, la vida religiosa revela en su ser y en su obrar, el amor de Dios a los hombres, a través de sus múltiples servicios de caridad. Se invitó así a caracterizar el ser y el obrar de este género de vida, no desde el punto de vista sociológico, es decir, no desde la valoración social de sus servicios, sino por razones teológicas y éticas. Todo ello promoviendo la vivencia de los valores cristianos, denunciando la violación de los derechos humanos de los más desfavorecidos de la sociedad y responsabilizando e implicando a otros en la misión y no sólo en su llamada a ser testigos del amor de Dios.

Con el segundo, la vida religiosa se convierte en un símbolo del único deseo auténtico del hombre: ver el rostro de Dios. Un anhelo que ha mani-

${ }^{20}$ Cf. A. CENCINI, Vida en comunidad, reto y maravilla: la vida fraterna y la nueva evangelización, Madrid 1997. 
festado en la riqueza de sus numerosas escuelas de espiritualidad, entendida esta última como la cultura específica del religioso, referente de valores y códigos interpretativos de lo real, que sintetiza la dimensión mística, ascética y apostólica del carisma y pide su traducción al tiempo actual, para penetrar las culturas de hoy.

Con la llegada de Juan Pablo II, Papa eslavo, situado a caballo entre Occidente y Oriente y entre la racionalidad y el misterio, se confirmó pronto la duplicidad del objetivo del nuevo pontificado, marcado por la recuperación de la identidad cristiana y el promover la misión, en torno a un hombre necesitado de redención. De aquí la Encíclica Redemptor Hominis (RH), que presentó al hombre, en la plena verdad de su existencia, de su ser personal y de su ser comunitario y social, como la primera vía que la Iglesia tiene que recorrer en el cumplimiento de su misión, siendo cada vez más consciente de ser la custodia de este gran tesoro, que debe crecer continuamente y ser contemplado con "los ojos de Cristo" (RH 18).Vía trazada por el propio Cristo y que pasa por el misterio de la encarnación y la redención (RH 14).

La misión es una nueva construcción, que comienza siempre con una profunda estima y respeto por la obra que el Espíritu realiza en el hombre (RH 12). Consiste en dirigir la mirada de éste, orientar su conciencia y su experiencia hacia el misterio de Cristo y tocar su corazón, posibilitándole su familiarización con la Redención, que se realiza en Cristo Jesús ( $\mathrm{RH}$ 10). Se trata de ayudarle a encontrar a Cristo, para que Éste pueda recorrer con él el camino de la vida, respondiendo así a su búsqueda de la verdad, a su insaciable necesidad del bien, a su hambre de la libertad y a su nostalgia de lo bello (RH 13).

Se recorrió así un buen trecho del camino para superar la crisis de misión de la vida religiosa dentro de una Iglesia, Pueblo de Dios, también en crisis de misión y de comunidades eclesiales que se hallaban en el mismo estado crítico. Por su parte, a la eclesiología del Pueblo de Dios, debía corresponder en la vida religiosa, una nueva toma de conciencia de lo que significa formar parte y ser Orden o Congregación, que supera notablemente la inserción en una pequeña comunidad. Sin embargo, habría que seguir haciendo hincapié hasta que toda la Iglesia se situase en auténtica actitud de misión y lograse ser verdadero Pueblo de pueblos.

\section{La década de los 80}

Tras el entusiasmo de los años 60 y la desazón de los 70, en la década de los 80 se sintió la necesidad de incrementar la tranquilidad y la seguridad. De la exaltación de lo colectivo y de la confianza en los grandes pro- 
yectos político-sociales se pasó a la centralización en la vida privada y a los pequeños proyectos. En este contexto, renació el "homo religiosus", pero su orientación narcisista se divulgó mediante formas exotéricas, hasta llegar a hablar de una «religión sin Dios» o de una «religión despersonificada».

En el ámbito de la eclesiología de comunión ${ }^{21}$, prosiguió la reflexión sobre el concepto de redención, aplicándolo a la complementariedad y circularidad entre los diversos carismas y estados de vida. A su vez se hizo evidente que no existe una receta universal para comprender el mecanismo de las vocaciones, sino que el Espíritu sopla donde quiere y cuando quiere y es necesario distinguir entre la «suerte histórica» de un carisma y su «función eclesial». Así, la Encíclica Redemptionis donum (RD) trató de subrayar lo que es perenne en la vida religiosa, indicando la íntima relación existente entre los consejos evangélicos y la economía de la Redención, la cual conduce al religioso a la destrucción inevitable de todo lo que es pecado y a la posibilidad de renacer cada día a un bien más profundo, que se halla ya escondido en el alma humana (RD 10).

Se le concedió mayor importancia a la fidelidad dinámica al propio carisma, que a las mismas obras o a la institución en sí, resaltando la identidad de éste, como un don dado a la Iglesia para su utilidad y desarrollo, en el que se manifiesta la conexión entre el amor de Dios y el amor al próximo.

No son las instituciones las que evangelizan, sino sus testigos, capaces de expresar su experiencia y de escuchar la de los demás en la vida cotidiana, evitando tanto la construcción de una fe demasiado ética e intelectual, como de una religiosidad dulce, adaptable según las necesidades subjetivas. Se invitó así a destacar la dimensión existencial, personal y vital de la fe, acentuando su carácter testimonial y profético como una forma de equilibrar la vivencia cristiana.

Si los años 60 tuvieron como punto central al seguimiento de Cristo y los años 70 al carisma, los años 80 se basaron en la consagración. En el documento Elementos esenciales de la doctrina de la Iglesia sobre la vida religiosa (EE) se partió de dicho concepto como una acción divina y gratuita, que requiere de una respuesta por parte del religioso, constituye el elemento base de la vida religiosa y comporta una misión. Ésta se realiza en el seguimiento de Cristo y en la fuerza del Espíritu, autor de la misión y de las misiones específicas, donde la Iglesia interviene, como mediadora de una consagración que representa una alianza de amor entre Dios y el hombre ${ }^{22}$.

${ }^{21}$ Cf. S. DIANICH, Chiesa estroversa. Una ricerca sulla svolta dell'ecclesiologia contemporanea, Cinisello 1987.

${ }_{22}$ "La misión de la Iglesia es ser signo, símbolo de la Gracia victoriosa de Dios sobre el mundo; ser la concreta manifestación histórica, en la dimensión de la historia que se ha 
El documento Dimensión contemplativa de la vida religiosa (DCVR) trató de las tradicionales problemáticas y antinomias que surgen en la relación entre Marta y María, entre la misión y la consagración. Integrando la interioridad con la apostolicidad, utilizando los medios concretos que proporciona la vida experimentada desde el Espíritu y evitando el peligro de caer en una implicación excesiva en el activismo, que conduzca al religioso a olvidarse del Dios cristiano, que precisamente ha de ser la fuente de motivación para el desarrollo de toda actividad (DCVR 4).

Se identificó a la dimensión contemplativa con la respuesta teologal de fe, esperanza y amor con la cual el creyente se abre a la revelación y a la comunión del Dios vivo por Cristo en el Espíritu Santo. Es el acto más pleno del Espíritu, que debe coronar la inmensa pirámide de una actividad humana, que abierta a la realidad de la creación y de la historia, se convierte en reconocimiento, adoración y alabanza constante de la presencia de Dios en el mundo y en su historia y en eco de una vida solidaria con los hermanos, sobre todo con los pobres y los que sufren (DCVR 1 y 5). No es una actividad únicamente exterior, sino la continuación de la misión de Cristo, en la historia del mundo, participando por tanto en la obediencia de Aquel que se ofreció a sí mismo al Padre por la vida del mundo (DCVR 6)

A su vez se presentó a la comunidad religiosa como una realidad teologal, objeto de contemplación, que constituye el lugar donde la experiencia de Dios debe poder alcanzarse particularmente en su plenitud y comunicarse a los demás (DCVR 15).

Por su parte, el documento Religiosos y promoción humana (RPU) animó a la búsqueda de nuevas formas de presencia, ofreciendo criterios de discernimiento ante las situaciones más expuestas a la ideologización y exhortando al religioso a no perder su identidad como tal. Para ello, en su número 13 , recordó al religioso la necesidad de mantenerse fiel al hombre y a su tiempo, a Cristo y al Evangelio, a la Iglesia y a su misión en el mundo ${ }^{23}$ y a la vida religiosa y al carisma del propio Instituto. Analizó cuatro problemas urgentes del momento: la opción por los pobres, las obras sociales de los religiosos, la inserción en el mundo del trabajo y el empeño directo en la política (RPU Introducción).

hecho escatológica y de la sociedad, de la salvación que mediante la gracia de Dios, se actúa en toda la longitud y amplitud del género humano" (J. C. R. GARCÍA PAREDES, imisión de la vida religiosa, Madrid 1982, 159).

23 "Por designio de Dios entendemos lo que Dios, desde su eternidad, pensó y proyectó con pensamiento creador sobre el mundo. $\mathrm{Y}$ entendemos "mundo", no como una magnitud estática, fija determinada, sino como el mundo de la historia, que está originándose históricamente de cara a la promesa del mundo nuevo; él es el despliegue de la historia del hom- 
La misión del religioso comienza por misionar su propio interior, para proyectarlo sobre los demás, reflejando los acontecimientos de la vida humana, a la luz de la historia de la salvación, anhelando la venida del Señor e invitando a transformar todo hecho histórico en alabanza, adoración, gratitud y súplica a la luz de la Pascua ${ }^{24}$. Se transforma en una sacramentalización histórica de la "missio Dei", capaz de transformar y revitalizar la sociedad, la cultura y el hombre de toda época ${ }^{25}$. De este modo, el religioso no puede quedarse en un simple análisis técnico del mensaje cristiano, sino que debe descifrar esa sed de alguien, que existe en todo acontecimiento humano, respondiendo como los apóstoles: "he visto" (Jn 21, 24-25) y "he encontrado" (Jn 1, 41, 45).

En este proceso, el religioso descubre su misión junto a los otros: si Dios lo llama por medio de los hombres, él no se vuelve hacia Dios si no con los hermanos para participar en su misma salvación. Se manifiesta así un Evangelio capaz de transformarlos hasta la plena madurez de Cristo (Ef $4,13)$. Es la liberación del egoísmo radical, para ser llevado a los otros por el amor incondicional de Dios, encontrando al Dios benévolo por mí en el Cristo hombre por los otros.

Se atendieron a temas importantes como la justicia, paz y cuidado de la creación, el diálogo interreligioso y el pensamiento posmoderno. De la pobreza económica se pasó a poner el acento en las nuevas formas de pobreza, fundamentalmente de naturaleza psicológica y relacional, como la pérdida del sentido de la vida, la soledad, la escasa satisfacción afectiva, los niños y ancianos abandonados, los inmigrados marginados, los enfermos mentales, los encarcelados, la droga y el Sida. Fue necesario correr el riesgo de la aventura que supuso el repensar las formas de apostolado, junto a los laicos, con modalidades inéditas, con perspectivas inciertas y con una cierta reorganización de las obras ${ }^{26}$.

bre, la historia absoluta y radicalmente nueva de cada persona humana, trenzada e intercomunicada con las historias, también absolutas y radicalmente nuevas de otras personas, generando así el mundo humano, la historia" (J. C. REY GARCÍA PAREDES, Misión de la vida religiosa..., 49).

${ }^{24}$ Cf. J. P. JossuA, La condición del testigo, Madrid 1987.

${ }^{25}$ Cf. J. A. GARCÍA, En el mundo desde Dios. Vida Religiosa y resistencia cultural, Santander 1989.

${ }^{26}$ Cf. J. SOBRINO, "La vida religiosa en el tercer mundo", en ID, Resurrección de la verdadera Iglesia, Santander 1981, 315-349; N. ZEVALLOS, Espiritualidad del desierto. Espiritualidad de la inserción, Bogotá 1982. 


\section{La década de los 90}

En los años 90 se extendió el proceso de globalización y su consecuente difusión de nuevos modelos culturales que, por medios de comunicación cada vez más rápidos y sofisticados, incidieron cada vez más profundamente sobre la mentalidad del pueblo cristiano. Del fenómeno económico-político dependía la paz y el mismo futuro del planeta, convirtiendo a la solidaridad en un desafío para la Iglesia y la vida religiosa, ante los contrastes existentes entre países ricos y países pobres y comunidades supranacionales. El fenómeno cultural incidió en el modo usual de pensar y de comportarse e impulsó a la vida religiosa a contribuir en la reconstrucción espiritual del hombre y la sociedad. Con el fenómeno religioso se asistió a la vuelta de la religión, pero comúnmente bajo formas de misticismo impersonal, fruto de la revolución individualista, vigente en aquel momento.

El documento La vida fraterna en comunidad (Vfc) se relacionó con el fenómeno económico, político y eclesial, describiendo a una comunidad religiosa, que participaba de la renovada visión de una Iglesia Misterio, Comunión y Sacramento, que animada por los carismas, hizo énfasis en la dimensión histórica, fraterna, apostólica y carismática de la comunidad religiosa (Vfc Introducción, 2).

En cambio, la Exhortación Postsinodal Vita Consecrata (VC) intentó responder a los fenómenos cultural y religioso, tratando como $\mathrm{Vfc}$, de combinar el desafío de la solidaridad con el de la fidelidad a Cristo, manantial de la reconstrucción espiritual del hombre y la sociedad. Desafíos que se derivaban de los numerosos cambios surgidos en diversos sectores sociales y del modo mismo de concebir la religión.

Vfc presentó la imagen de una comunidad misionera llamada a vivir la hermandad, en su fuerza apostólica, y a anunciarla con su testimonio, siendo en la Iglesia y por la Iglesia, una señal e instrumento de la unión del hombre con Dios y de los hombres entre sí. Es un don, que forma parte del proyecto de Dios, consistente en su deseo de comunicar su vida de comunión, un lugar donde se llega a ser hermanos y el lugar y sujeto de la misión (Vfc 7).

La comunión y la misión están profundamente unidas, se compenetran y se implican naturalmente, hasta el punto de que la comunión representa la fuente y, al mismo tiempo, el fruto de la misión y la misión es tal en orden a la comunión, haciéndose anuncio, diakonía y testimonio profético del Resucitado, quien vive en la comunidad (Vfc 58). Una misión que ha de salvaguardar las obras que mejor desarrollen el carisma y la vida fraterna, tener presentes las necesidades de la Iglesia local y universal y privile- 
giar las realidades desechadas por el mundo, reviviendo las grandes dimensiones del éxodo (desestructurar para reestructurar), del destierro (reconstruir sobre nuevas bases) y de la poda (obtener de la pobreza, la máxima bendición o riqueza).

Una complementariedad en cuyo seno subyacen las numerosas páginas de la historia de la humanidad, que fueron escritas gracias a los religiosos. La Iglesia reafirma esta realidad cuando en LG 46 o en GS 1, reconoce que la vida religiosa en todas sus formas no es extraña a la humanidad, ni inútil para la ciudad terrena.

Sin embargo, en esta década se asistió al paso de una religión sin mundo, a un mundo sin religión, donde ciertas antropologías secularistas consideran que la misión del hombre es aquella que él mismo se asigna, en cuanto que se autofundamenta, autoconstruye y autoproyecta, o la misión que la realidad externa le impone. En cambio, existen otras antropologías, que partiendo de la experiencia y de la capacidad de autotrascendencia del hombre, están abiertas a una interpretación religiosa de la realidad, recuperando el Evangelio de la encarnación.

Se manifiesta cómo en cada hombre se condensa la experiencia continuada que tiene la humanidad de ser portadora de algo que no posee plenamente en sí misma y por lo que aspira. Se reafirma a Dios como esa respuesta a la búsqueda de fundamento y sentido ${ }^{27}$, que nos recuerda la vocación a la libertad de todo ser humano. Éste apoya su existencia en la búsqueda de una libertad cada vez más plena, a través de un proceso de liberación, que inspirado en el amor, lo saca de su concentración egoísta, haciéndolo portador de vida para el otro.

El hombre aprende a través del contacto inmediato con los otros o con las cosas, saliendo de sí mismo para después retornar sobre sí y hacer entrar en dialéctica lo aprendido fuera, con lo sabido dentro. Un aprendizaje que se realiza con todo el ser y el tener, se expresa mediante el lenguaje y conduce hacia un nuevo modo de pensar, amar y ser libre, que muestra cómo el hombre es trascendencia, realiza su propio ser superándose a sí mismo y se actualiza en tanto que se trasciende, no sólo encontrando a Dios, sino también dejándose encontrar por Él.

De este modo, el hombre se hace portador de una vida que se concretiza en sentimientos y prácticas de acogida pacífica y de apertura confiada

27 "El anhelo de Dios, de verdad, de bien y de belleza, la búsqueda de un amor que corresponda plenamente al corazón y de una felicidad verdadera y que permanezca en el tiempo, son de tal modo la marca de lo humano, que constituyen al hombre como hombre" (OBISPOS DEL SUR DE ESPAÑA, Os anunciamos la vida eterna... para que vuestro gozo sea completo, 1 de noviembre de 1998, 4). 
y sin miedos hacia el porvenir, liberándose del individualismo, que incapacita para amar, de un ejercicio de la libertad que acaba esclavizando y del pesimismo ante un futuro que parece no ofrecer esperanzas.

En esta experiencia el hombre no es el agente, sino el paciente, que descubre que no existe por sí mismo, sino que su ser lo ha recibido de otro y que su vida está permanentemente caracterizada por la misión, hasta tal punto que la constituye. No es que la vida tenga misión, sino que es misión $^{28}$, que transforma a la existencia no en una espléndida posibilidad, sino en un mandato, que se impone al hombre y que en cuanto tal le impulsa a vivir.

La misión del hombre no sería entonces un futuro al que llega o que genera, sino un adviento para el que se dispone humilde y agradecidamente, sabiéndose llamado a la existencia por Dios y enviado por Él a la historia. Su misión no la debe de desarrollar como una simple ejecución, sino que tiene que tener en cuenta sus miembros intencionales, imprimiendo su huella en el mundo, pero sobre todo configurándose a sí mismo y entrando en el íntimo conflicto entre lo que es y lo que quiere ser. De este modo, el hombre, en efecto, es vocación, que trata de transformar la realidad y es transformado por ella, reflejando en sí mismo su propia acción, en cuyo cumplimiento halla la verdad de su $\operatorname{ser}^{29}$.

Inspirándose en estas realidades de fondo, el documento Vfc exhortó a vivir en una madurez teologal, mirando con fe y esperanza a la misma comunidad religiosa, que se sitúa en la economía presente del Reino de Dios, es decir del «ya», pero «todavía no». Presentó a la misma como una «schola amoris», donde se aprende a querer a Dios, a los hermanos y a la humanidad, por encima del propio interés (Vfc 25).

A su vez impulsó a potenciar una madurez ascética y espiritual, subrayando la necesidad de mirar dentro de sí y recordando la responsabilidad personal en la construcción de la comunidad religiosa (Vfc 35, 36 y 39).

Así mismo invitó a emprender una madurez cultural (Vfc 36), donde converjan una formación ascética, que pone el acento sobre el desarrollo de las virtudes; una formación teológica, que se enfrenta a los problemas actuales, situándolos en el contexto de la teología y la cultura contemporánea; una formación jurídica, que propone determinados cambios normativos, que considera necesarios para el buen funcionamiento de la comunidad; una formación antropológica; que propone un mejor conocimiento de la psicología para poder aplicarla al análisis de la persona y de la sociedad.

\footnotetext{
${ }^{28}$ X. ZUBIRI, Naturaleza, historia y Dios, Madrid $1977^{7}, 371$.

29 "Siempre le ha interesado al hombre saber quién es" J. DE SAHÁGÚN, 17.
} 
Finalmente propuso una madurez operativa, consciente de la creciente complejidad de las diversas actividades que solicitan competencias cada vez más avanzadas y una colaboración cada vez más articulada entre la vida religiosa y la iglesia particular (Vfc 60-61), la vida religiosa y los movimientos eclesiales (Vfc 62), así como entre los religiosos y los laicos (Vfc 70).

$\mathrm{Al}$ mismo tiempo, la realidad social puso de manifiesto cómo la principal preocupación residía no en la escasez de religiosos profesionalmente especializados, sino en la crisis de función eclesiológica y teológica, según la dinámica intrínseca de los propios carismas.

Con la Encíclica Redemptoris Missio (RM), publicada el 7 de diciembre de 1990, en el XXV aniversario del Decreto AG, el Papa quiso recordar cómo la actividad misionera no es una tarea al margen de la Iglesia, sino que se halla inserta en el corazón de su vida, como compromiso fundamental de todo el Pueblo de Dios. Para ello, en el número 32 de dicho documento resaltó el nuevo aliento que supuso en este tema el llamado reingreso de las misiones en la misión de la Iglesia, la confluencia de la misionología en la eclesiología y la inserción de ambas en el proyecto trinitario de la salvación. A su vez, contribuyó a superar algunas tendencias negativas, señalando que los ámbitos confiados a la misión no sólo se ejercen en territorios y entre grupos humanos bien delimitados, sino que sus lugares privilegiados son los espacios en que surgen nuevas costumbres y modelos de vida.

Se definió a la misión como el índice exacto de nuestra fe en Cristo y de su amor por nosotros (RM 12), que exhorta a una conversión continua a la obediencia al plan divino, dejándose conducir por el Espíritu hacia la más profunda experiencia del ser querido por Dios Padre en su Hijo Jesús. Que conduce a realizar todas las formas de la actividad misionera de la Iglesia desde la fidelidad a Cristo y el empeño por la promoción de la libertad del hombre, encarnando el Evangelio en las culturas de los pueblos.

La Exhortación apostólica postsinodal VC presentó a una vida consagrada inserta en el corazón de la Iglesia, como elemento decisivo para su misión, ya que indica la naturaleza íntima de la vocación cristiana y la aspiración de toda la Iglesia Esposa hacia la unión con el único Esposo (VC 3). Distinguió entre los tres elementos fundamentales que componen la misión de la vida consagrada: la consagración, la vida fraterna en comunidad y la misión específica (VC 13).

La consagración se hace eco del "sí" incondicional de María e indica que la vida consagrada está ya en misión por el hecho de anunciar la forma de vida de Cristo, proclamando que está vivo y actúa, aún en un mundo que tiende a borrar su memoria (VC 18). El religioso es enviado al mundo 
para imitar más de cerca el ejemplo de Jesús y continuar su misión, haciendo de Él el todo de su existencia ${ }^{30}$. No sólo ha de dedicarse totalmente a la misión, sino que su vida, bajo la acción del Espíritu Santo, fuente de toda vocación y carisma, se hace misión, como fue la misma vida de Jesús.

Por consiguiente, no se trata de hacer obras exteriores, sino de hacer presente a Cristo en el mundo dejándose conformar a Él, en virtud de su misma consagración, manifestada según el proyecto del propio Instituto (VC 72). De este modo la vida consagrada se hace memoria viviente del modo de existir y de actuar de Jesús como Verbo encarnado ante el Padre y ante los hermanos (VC 22) y coopera eficazmente con la misión de Éste, en la medida en que hace de su vida una entrega continua al Padre, sostenida por Cristo y animada por el Espíritu, contribuyendo de forma particularmente profunda a la renovación del mundo (VC 25).

La vida fraterna en comunidad es la misión, señalando una vida social nueva, caracterizada por la realización de la fraternidad (VC 45, 51). La vida religiosa será tanto más apostólica, cuanto más íntima sea la entrega al Señor Jesús, más fraterna la vida comunitaria y más ardiente el compromiso en la misión específica del Instituto (VC 72), uniendo autoevangelización y testimonio, renovación interior y apostólica y ser y actuar (VC 81).

La misión específica es la participación en una faceta particular del misterio de Cristo, a través del apostolado, que determina la operatividad de un Instituto. La vida religiosa tiene la misión profética de recordar y servir el designio de Dios sobre los hombres, para lo cual el religioso ha de poseer una profunda experiencia de Dios y tomar conciencia de los retos del propio tiempo, captando su sentido teológico mediante el discernimiento efectuado a la luz del Evangelio y con la ayuda del Espíritu Santo (VC 73).

Existe, no a pesar de la historia, sino dentro de la historia y por la historia, para dar respuestas históricamente relevantes, no sólo leyendo las señales de los tiempos, sino también escribiendo nuevas. No sólo aceptando desafíos, sino construyendo nuevos y no sólo anunciándolos, sino también en cierto sentido, anticipando el tiempo futuro (VC 32), de manera que pueda responder a los interrogantes sobre el sentido y la relación entre la vida presente y futura.

Un elemento importante en este proceso es la inculturación, la cual consiste en saber buscar y encontrar huellas de la presencia de Dios en la

30 "La vida religiosa cumple su misión solamente si es memoria viva de la existencia, de la acción y del estilo de Jesús; los religiosos están presentes en la Iglesia para encarnar, vivir y recordar todos los gestos y las actitudes que Jesús vivió en su vida humana entre nosotros, los hombres, y en su misión" (E. BIANCHI, "¿Qué profecía ofrece la vida religiosa a nuestro tiempo?” en AA. VV, ¿Es profética la vida consagrada? (Jr 1,5), Madrid 2008, 22). 
historia de las personas y de los pueblos, que guían a la humanidad entera hacia el discernimiento de los signos de su voluntad redentora. Ello ayuda a incrementar el compromiso del religioso respecto a la contemplación y la oración, a su vivencia del compartir comunitario, a la hospitalidad y al cultivo diligente del interés por la persona y el respeto por la naturaleza (VC 79).

Por tanto, la cuestión que se planteó no fue tanto en qué aspectos se diferencia la misión del religioso y de su comunidad de la misión del hombre o la misión de la Iglesia, cuanto en qué medida la misión de la vida religiosa no es sino la misión del hombre y la misión del seguidor de Jesucristo y de la Iglesia ${ }^{31}$. Una misión que procede de un mandato o encargo de Cristo de acercarse a cada hombre, en su realidad concreta, cultural e histórica y obrar en nombre de Dios, abriéndole así en medio de sus sufrimientos un camino de esperanza, que es confianza y tensión hacia el Reino definitivo y hacia la restauración final en Cristo.

La misión de la vida religiosa está en continuidad con una compleja y variada tradición carismática dentro del propio Instituto y fuera del mismo, pero en el marco de las diversas formas históricas de vida religiosa. Son estas tradiciones las que configuran el rostro misionero de la comunidad religiosa y la constituyen en memoria de un pasado de logros y de fracasos, pero también en memoria incitante hacia un futuro de fidelidad creadora, liberándose de la rutina del que cree que lo sabe todo y abriéndose a una sensibilidad, que se mantiene en expectativa ante las necesidades del otro.

Se trata de predicar la visión cristiana de la existencia, desde el Cristo muerto y resucitado, que dona el Espíritu para la remisión de los pecados (Hech 2, 22-24). En Él está resumido todo el pasado, desde la profecía antigua hasta la muerte de Jesús de Nazaret; el presente se nutre del entusiasmo del Espíritu; el futuro es aguardado con una esperanza que no decepciona. De una audacia en el anuncio que debe estar acompañada de la confianza en la acción de la Providencia, que actúa en el mundo y que "hace que todas las cosas, incluso los fracasos del hombre, contribuyan al bien de la Iglesia" (VC 81). Confiar en Dios como si todo dependiese de Él y, al mismo tiempo, empeñarse con toda generosidad como si todo dependiera de nosotros (VC 73) ${ }^{32}$.

${ }^{31}$ Cf. J.C.R. GARCÍA PAREDES, Misión de la vida religiosa ..., 24.

32 "En este fundamental sentido, llamaba al hombre el sujeto emprendedor. Y añadía, existir humanamente es, por supuesto, pasión de ser, ontopathesis, pero también es, de modo más alto y decisivo, creación de ser, ontopoiesis. Pasión de ser, porque el hombre no viene de sí mismo, ni ha podido elegir libremente su existencia. Se encuentra con ella como un dato irrefutable, previo a toda posible acción y reacción suya. Existir, para él, es ciertamente un 
Es necesario ser fiel a Jesucristo y no fijarse sólo en las dificultades del mensaje, sino en las oportunidades que se presentan a través de los aerópagos de cada época histórica. El primer areópago del tiempo moderno es el mundo de la comunicación, que está unificando a la humanidad y transformándola en una "aldea global", convirtiéndose para muchos en el principal instrumento informativo y formativo y de orientación e inspiración para los comportamientos individuales, familiares y sociales. Existen otros areópagos del mundo moderno hacia los cuales debe orientarse la actividad misionera de la Iglesia, como el compromiso por la paz, el desarrollo y la liberación de los pueblos; los derechos del hombre y de los pueblos; la promoción de la mujer y del niño; el cuidado de la creación.

La Instrucción Caminar desde Cristo: un renovado compromiso de la Vida consagrada en el tercer milenio $(\mathrm{CdC})$ afirmó la necesidad de reforzar la vida espiritual y la comunión, como base para sostener la renovación de la vida religiosa, hasta transformar al religioso en un testigo del amor divino. Se le exhortó a caminar desde Cristo, es decir, a reencontrar el destello inspirador con que comenzó el seguimiento del mismo, el cual es sólo la respuesta de amor al amor de Dios. Una respuesta que se nutre de la vivencia de los consejos evangélicos, que facilitan la permanencia a dicho amor, fomentando la docilidad del religioso a la voluntad del Amado; la vida fraterna, que tiene como fin gozar de su constante presencia; la misión, que es su mandato y conduce a la búsqueda de su rostro en el de aquellos a los que es enviado, para compartir con ellos la experiencia de Cristo (CdC 22).

Este género de vida se hace misión cuando se deja conformar a Cristo, haciéndolo presente y operante en la historia como el porvenir de una humanidad en camino, que mira hacia el futuro con sabor de resurrección (CdC 9). Es memoria viviente del modo de existir y de actuar de Jesús como Verbo encarnado ante el Padre y ante los hermanos, que conlleva una particular comunión de amor con Él, constituido el centro de la vida y fuente continua de toda iniciativa (CdC 22). Es la presencia de la caridad de Cristo en medio de la humanidad, guiada por un Espíritu que también

privilegio, pero también una obligación y una necesidad. Pero el hombre es, de un modo más alto y decisivo, como afirma Laín, creación de ser, ontopoeta, poeta del ser, artífice y artesano de su propio destino, faber suipsius. Sólo él, entre todos los seres del universo, tiene la extraña y formidable capacidad de hacerse y al mismo tiempo, la dolorosa posibilidad de deshacerse. Y es que el hombre no es nunca seguramente hombre, porque está siempre a punto de no serlo. Por eso, es viviente problema, azarosa aventura, es decir, un verdadero drama. Sólo hay drama cuando no se sabe lo que va a pasar, sino que cada instante es puro peligro y trémulo riesgo" (S. M. ALONSO, Vivir en Cristo: El misterio de la existencia, Madrid 1998, 28). 
actúa dentro de las dificultades y las pruebas. Un Espíritu que conduce hacia nuevas estaciones de vida evangélica, recorriendo caminos de renovación y purificación, en torno a la Palabra de Dios y a la comunión dentro y fuera de la comunidad religiosa, entre los carismas antiguos y nuevos y entre los Pastores y los laicos.

Se hace eco de la misión de la Iglesia, la cual en su dinámica trinitaria, se origina en el Padre, pasa por la generación del Verbo y la inspiración del Espíritu. Es constituida con la encarnación y retorna al Padre por el Hijo, en quien se manifiesta, realiza y comunica la misión del Padre, conformando a los hombres a sí, el Primogénito entre muchos hermanos, para construir una comunidad eclesial donde se recupere la dignidad del hombre y la unidad solidaria de toda la comunidad humana.

$\mathrm{Su}$ responsabilidad misionera se concreta en toda vocación cristiana, según la propia peculiaridad laical, como inserción en las estructuras humanas a modo de fermento evangélico; de vida consagrada, como radicalismo evangélico profesado con especiales vínculos; de vida sacerdotal, como representación de Cristo Buen Pastor. Gira en torno a Jesucristo, a través de una relación personal con Él (oración), celebrando sus misterios (liturgia), configurándose con Él (espiritualidad) y anunciándolo a los hermanos (pastoral, misión).

Sin embargo, son varias las interpretaciones que existen en torno a la figura de Jesús, influenciadas en su mayor parte por el desarrollo actual de una fe cristiana que cesó de ser un hecho sociológico, para insertarse en una imagen errónea del cristianismo, identificado con un ciclo histórico concluido, que considerado ya incapaz de originar nuevas esperanzas históricas, fue relegado al plano de lo personal, privado y subjetivo.

En los últimos siglos, el hombre se liberó de divinidades opresoras que le impedían ser él mismo. Al prescindir de Dios daba la impresión de que no sabía hacia dónde mirar, originándose un vacío de identidad humana, que requiere el descubrir que el verdadero Dios no es el opresor o el rival del hombre, sino el que le da consistencia y afirma su identidad, Hch 17, $28^{33}$.

La desaparición del Dios creador del mundo, trae consigo no sólo su muerte, sino también la muerte progresiva de un hombre, que tiene la tarea de entender y ordenar a un mundo convertido en un caos. El sujeto humano se siente desgajado de los grandes relatos religiosos, que dieron sentido a las generaciones pasadas, concentrándose en el presente como si fuese el tiempo final. Convierte a la religión en un conjunto de historias

\footnotetext{
33 "Fuera de la Biblia, el hombre hace dioses a su imagen, en la Biblia Dios hace al hombre a su imagen" (J. L. DE LA PEÑA, Imagen de Dios..., 45).
} 
que tratan de incitar a abandonar las ilusorias aspiraciones acerca de una felicidad eterna, para aceptar la realidad de la condición humana, invitando a dar la propia vida para el bien de la humanidad.

Una exhortación a abandonar al Dios abstracto y a cimentarse en un Cristo, que choca con la mentalidad relativizadora de una sociedad pluralista y democrática en la que casi todo es negociable. De este modo se pone en juego la normatividad de Cristo para la existencia humana, convirtiéndolo en uno más de los hombres interesantes, pero difícilmente en una referencia obligada y decisiva para la propia vida. A su vez se corre el riesgo de interpretarlo al margen de su relación con Dios o incluso negar explícitamente la misma, con la intención de obtener su intrínseca fuerza humana y convertirlo no en un revelador de Dios, sino del hombre y de sus pretensiones últimas ${ }^{34}$.

Para otros Jesús habría sido un inspirador y animador original de valores religiosos, que proclamó un mensaje que le superaba y trascendía. Un anunciador de un Dios trascendente, considerado como el totalmente Otro, cuyos proyectos resultan inaccesibles para el hombre, quien únicamente podía y debía aceptar los hechos.

Sin embargo, en el acontecimiento Jesucristo, se manifestó que la auténtica identidad de la humanidad sólo se puede construir cuando ésta se deja transformar por la misericordia de Dios, por el amor gratuito a los demás y por una confianza sin límites en el futuro, aceptando libremente morir por el otro, para darle vida.

El Dios revelado por el Jesús histórico no impone la aceptación de su existencia, ni exige que por miedo al castigo, los seres humanos reconozcan su intervención, sino que se manifiesta como parábola o manifestación única y singular del Padre, cuyo poder es amor gratuito, incontrolable y humanamente no razonable, que introduce en la historia la tensión entre lo nuevo y lo antiguo, el reino y la ley, la novedad y la memoria. Es el esperado que rompe las esperanzas de triunfalismo mesiánico y en su realidad histórica de hombre fracasado y excluido, destruye todas las imágenes de la divinidad construidas con la racionalidad metafísica ${ }^{35}$ o estética y exhorta a ponerse en camino hacia lo desconocido y sorprendente. Es el amor que

\footnotetext{
34 "Eliminar de la vida de Jesús esta relación a Dios equivale a negar la propia identidad histórica de Jesús y a hacer de él una esencia a-histórica" (E. SCHILLEBEECKX, "El Dios de Jesús y el Jesús de Dios", en Concilium. 93 (1974), 433-434).

35 "La encarnación es esencialmente histórica; incluye el proceso de asumir, experimentar, compartir, convivir una historia de hombre. La encarnación incluye el proceso del hacerse sucesivamente hombre. $Y$ hacerse hombre como nosotros implica: asumir nuestra condición de hombres. Asumir nuestra libertad finita, propia del homo Viator. Asumir la temporalidad y la historicidad. Asumir la finitud y la mortalidad" (B. FERNÁNDEZ, El Cristo del seguimiento, Madrid 1995, 251-252).
} 
gratuitamente se ofrece, no como un libertario, o un piadoso dogmático, sino como un liberal que relativizó leyes y preceptos cuando estaba en juego la vida de las personas.

Existe un fundamental acuerdo entre los exégetas en afirmar que Jesús apareció en medio del Israel de su tiempo como un profeta o un hombre con pretensiones proféticas ${ }^{36}$. En su bautismo, Jesús, ungido por el Espíritu profético es proclamado por Dios, como su hijo y siervo, destinado a ser inmolado tras anunciar el juicio salvífico sobre todos los pueblos. De tal modo que se establece una doble relación entre el Padre y el Hijo; generación-procedencia y misión histórica. No hay misión sin filiación, ni filiación sin misión ${ }^{37}$.

Jesús se identifica con el Mebasser y anuncia la inauguración inminente del Reino de Dios en beneficio de los pobres, es decir, de los que poseen una marginación de cualquier tipo, como un acontecimiento que penetra la historia y la lanza hacia el futuro, exigiendo al hombre una decisión incondicional, una entrega total de sí y la adopción de la conversión como su concreta configuración. Su acción está decididamente volcada a favor de la liberación total del hombre, que en su radicalidad es liberación del pecado, pero que en sus manifestaciones es liberación de todo tipo de esclavitud, enfermedad y necesidad, presentadas como estados de posesión diabólica (Mt 4, 23-25; Is 61, 1).

El encuentro definitivo con el Padre, el retorno a la casa paterna después de peregrinar como un desterrado por nuestra historia, constituye a Jesús como el Hijo del Padre, que hace culminar su misión y convierte a la humanización de Dios en la máxima posibilidad de realización humana ${ }^{38}$. Porque no hay gloria de Dios sin glorificación del hombre, ni hay gloria del hombre sin glorificación de Dios ${ }^{39}$.

La vida religiosa ha tenido siempre como referencia esencial y constitutiva la persona de Jesús, representando mediante sus variadas formas, los

${ }^{36}$ Cf. J.C.R. GARCÍA PAREDES, Misión de la vida religiosa ..., 70.

37 "El nombre Jesucristo incluye dos palabras: Jesús y Cristo. La primera se refiere a un judío sometido a los condicionamientos de cualquier persona humana: espacio, tiempo, cultura. La segunda se refiere al Unido, Enviado, el Hijo. Pero las dimensiones histórica y trascendente, humana y divina, se dice de un solo sujeto; van inseparablemente unidas, de forma que Jesús es el Cristo y Cristo es Jesús. Por eso resulta de sumo interés conocer la humanidad, al Jesús que vivió, caminó y actuó en nuestra tierra como un hombre entre los hombres" (J. ESPEJA, Creer en Jesucristo, Madrid 1997, 103).

38 "Cristo, hombre entre los hombres, ha venido a confirmar decisivamente el valor absoluto de la persona humana" (J. L. RUIZ DE LA PEÑA, Imagen de Dios..., 178-179).

39 "La gloria de Dios es que el hombre viva, y la vida del hombre es la visión de Dios" (San Ireneo, IV, 20, 7, en AA. VV., DP, Sígueme 1991, 1101). 
diversos aspectos de la misión del mismo (AG 18). Debe ser testigo en el mundo de la unión íntima con su vida, sentimientos, pensamientos, palabras y obras. Ello le lleva a la donación de sí misma, es decir a ponerse al servicio del mundo y de la misma familia religiosa, siguiendo el ejemplo de Jesús, quien ofreció su vida para nuestra salvación.

El sujeto que lleva adelante la misión es el mismo Jesús, quien trajo la salvación con sus obras y sus palabras, insertadas en una cultura, a cuantos se encontraron con el amor y la misericordia de un Dios cercano, que se hallaba en una continua dinámica de relación con la humanidad. Es el modelo y el contenido de la misión, que nos enseña la eficacia en el obrar, la pobreza en el tener y la humildad en el aparentar, como características esenciales de todo apostolado.

Es en la oración donde se establece ese diálogo con Él, que ayuda al religioso a reencontrarse con Dios en la interioridad de sí mismo, a fortalecer su relación con Jesús y a seguirlo con fidelidad, desde el reconocimiento humilde de su condición de pecador, que lo conduce a la renovación del hombre interior.

Es ahí donde se descubre la síntesis de todo lo que hemos estado diciendo a lo largo de estas páginas: la misión de la vida religiosa es la misma misión del hombre, del cristiano y de la Iglesia, que consiste en autotrascenderse dentro de la historia y por la historia, como memoria incitante ${ }^{40}$ hacia un futuro de fidelidad creadora, que transforma la realidad y se deja transformar por ella. Ésta se realiza en obediencia a la Palabra, la cual revela el amor de Dios al hombre y el deseo de éste de ver el rostro de Dios; manifiesta a Cristo como el Hijo enviado por el Padre, quien otorga el significado a la propia vida, a través de la unión con Él y su misión; capacita para responder a las exigencias del hoy, renovando a la humanidad, a la luz de la Pascua.

La misión del religioso es un aprendizaje que le enseña a recorrer pacientemente su propio camino, único y original, sin desistir de la marcha, por la fatiga, ni anticipar la llegada a la meta, por la largueza. En ese caminar, el religioso sabe que no está solo, sino que le acompaña el Resucitado, cuyas palabras le llenan de nuevo aliento: "Yo estaré con vosotros todos los días hasta el fin del mundo" (Mt 28,16-20).

40 "Es inevitable mirar hacia atrás de vez en cuando y contemplar nuestra historia. Y según sea nuestra mirada así será nuestro presente y tal vez nuestro futuro. Es verdad que nuestra historia, no volverá. Pero de alguna manera vuelve en la interpretación que damos al camino recorrido. Porque si es verdad que ya no podemos alterar ni un solo minuto, ni cambiar ni un solo acontecimiento de nuestro pasado, no es menos cierto que ese pasado puede alterar y condicionar para bien o para mal nuestro futuro" (A. FERNÁNDEZ BARRAJÓN, Brisa y arena. 11 reflexiones sobre la vida consagrada y una carta de amor, Madrid 2007², 70). 